\title{
Anthropology and Development
}




\author{
Also by Lucy Mair \\ Primitive Government \\ New Nations \\ Witchcraft \\ Anthropology and Social Change \\ An Introduction to Social Anthropology \\ Marriage \\ African Societies \\ African Kingdoms
}




\title{
Anthropology and Development
}

\author{
Lucy Mair
}

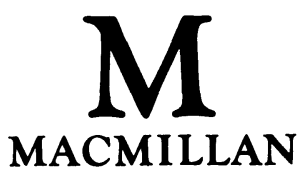




\section{(c) Lucy Mair 1984}

All rights reserved. No reproduction, copy or transmission of this publication may be made without written permission.

No paragraph of this publication may be reproduced, copied or transmitted save with written permission or in accordance with the provisions of the Copyright, Designs and Patents Act 1988, or under the terms of any licence permitting limited copying issued by the Copyright Licensing Agency, 90 Tottenham Court Road, London W1P 9HE.

Any person who does any unauthorised act in relation to this publication may be liable to criminal prosecution and civil claims for damages.

First published 1984 by THE MACMILLAN PRESS LTD

Houndmills, Basingstoke, Hampshire RG21 2XS

and London

Companies and representatives

throughout the world

ISBN 978-0-333-36371-3 ISBN 978-1-349-17445-4 (eBook)

DOI 10.1007/978-1-349-17445-4

Reprinted 1987, 1992 


\section{Contents}

Acknowledgements

vii

1 What is Development? 1

What is Development? 1

Development in the Post-colonial World 3

Development Policies $\quad 8$

What has the Anthropologist to say? 10

2 Modes of Livelihood 15

Nomadic Peoples $\quad 15$

Farmers or Peasants? 21

The Legacy of Colonial Rule $\quad 27$

3 Family and Kinship $\quad 30$

Types of Family $\quad 30$

Special Problems of Matriliny $\quad 34$

Female-headed Families $\quad 36$

The Family Dwelling $\quad 40$

Family Rituals 43

4 Land Rights, Land Reform, Land Improvement 46

Traditional Land Rights 46

Land Reform Policies 53

Collectivization $\quad 56$

Extension Services $\quad 62$

5 Women in Rural Life 67

Women's Work in the Family and Household 68

Women's Incomes $\quad 72$

Who Receives Cash Income and how is it Allocated? 
vi Contents

6 Equality $\quad 82$

Possible Bases of Inequality $\quad 84$

$\begin{array}{ll}\text { Development } & 87\end{array}$

Attitudes Towards Inequality in Africa 90

7 Enterprise and Entrepreneurs 95

Motivating Factors $\quad 96$

The Small Entrepreneur $\quad 100$

The Informal Sector 103

8 Man-made Lakes and Resettlement 108

Displaced Populations 108

The Kariba Dam $\quad 110$

The Volta Move 113

Needs to be Met 116

9 Cities and Slums $\quad 121$

Migrations to Cities $\quad 122$

Slums of Hope $\quad 126$

Slum Clearance in Singapore $\quad 128$

Slum Clearance in Africa 130

10 Envoi $\quad 135$

Bibliography 136

$\begin{array}{ll}\text { Index } & 140\end{array}$ 


\section{Acknowledgements}

The author and publisher wish to thank the following who have kindly given permission for the use of copyright material: Penguin Books Ltd for an extract from Walter Elkan, An Introduction to Development Economics (Penguin Education, Revised edition 1976) p. 141. Copyright (C) Walter Elkan, 1973. Reprinted by permission of Penguin Books Ltd; and the Reserve Bank of India for the extract on pages 64-5. 